\section{Result of Twin Pregnancies at the Maternity of Ignace Deen National Hospital in Guinea}

\author{
Balde Ousmane', Diallo Mamadou Hady', Balde Ibrahima \\ Sory ${ }^{2 *}$, Diallo Fatoumata Bamba', Houssainatou $\mathrm{Sy}^{2}$, Sow \\ Alhassane $I^{2}$, Diallo Ibrahima Tangaly ${ }^{2}$ and Sy Telly ${ }^{2}$
}

${ }^{1}$ Department of Obstetrics and Gynecology, Donka National Hospital, Conakry $\mathrm{CHU}$, Guinea

${ }^{2}$ Department of Obstetrics and Gynecology, Ignace Deen National Hospital, Gamal Abdel Nasser University of Conakry, Conakry CHU, Guinea

\begin{abstract}
Introduction: Twin childbirth is a high-risk childbirth especially for the $2^{\text {nd }}$ Twin, whose perinatal mortality was increased by $\left(102.8 \%_{0}\right)$. The aim of this study was to describe the outcome of twin pregnancies in an African setting at the maternity ward of the Ignace Deen National Hospital.

Methodology: This was a prospective study of a descriptive and analytical type lasting twelve (12) months from January 1 to December 31,2020 carried out at the obstetric gynecology department of the Ignace Deen National Hospital.

Results: The frequency of twin pregnancies (GG) was $4.62 \%$ of deliveries. Pregnant women aged 25 to 29 were in the majority $(81.74 \%)$. The socio-demographic profile of the woman who gave birth to twins was that of a housewife (32.8\%), unschooled $(42.4 \%)$, married $(96 \%)$ and pauciparous $(35.6 \%)$. The delivery was at term in $51.38 \%$ of cases and the anatomical type most frequently encountered was dizygous $(90.51 \%)$ and premature in $48.62 \%$. The early neonatal prognosis was good in $59.09 \%$ of cases for D1 and $66.4 \%$ for D2. We noted respiratory distress in $24.51 \%$ of cases for D1 and $37.55 \%$ for D2 and perinatal mortality of $79.1 \%$ for D1 and $102.8 \%$ for $\mathrm{J} 2$. The factors of the poor neonatal prognosis were prematurity, low birth weight and vaginal delivery for the 2 nd twin. The immediate maternal prognosis was good in 227 patients and marked by postpartum hemorrhage in 26 patients, including three (3) maternal deaths.
\end{abstract}

${ }^{\star}$ Corresponding author: Balde Ibrahima Sory, Department of Gynecology and Obstetrics, Ignace Deen National Hospital, Gamal Abdel Nasser University of Conakry, Conakry CHU, Guinea, Tel: +00224 622269858; E-mail: baldeisory@ yahoo.fr

Citation: O Baldé, MH Diallo, IS Baldé, FB Diallo, H Sy, et al. (2021) Result of Twin Pregnancies at the Maternity of Ignace Deen National Hospital in Guinea. J Reprod Med Gynecol Obstet 6: 079.

Received: May 28, 2021; Accepted: June 05, 2021; Published: June 11, 2021

Copyright: (๑) 2021 O Baldé, et al. This is an open-access article distributed under the terms of the Creative Commons Attribution License, which permits unrestricted use, distribution, and reproduction in any medium, provided the original author and source are credited.
Conclusion: The improvement of the neonatal prognosis in the event of twin pregnancy would require an early ultrasound between 12 - 15 weeks old, systematic corticosteroid therapy in the event of a threat of premature birth (PAD) before 34 weeks old and the performance of an ultrasound in the ward.

Keywords: Maternal and fetal prognosis; Prenatal monitoring; Twin pregnancy

\section{Introduction}

Twin pregnancy is considered a high risk pregnancy, because of perinatal mortality, the frequency of fetal morbidity it causes but also because of the complications it poses to the mother during pregnancy such as toxemia, pregnancy, bleeding from delivery [1]. This excess of perinatal morbidity and mortality is essentially related to prematurity, the incidence of which is multiplied by 6 and Intrauterine Growth Retardation (IUGR), the incidence of which is multiplied by 3 [2]. Prematurity is the pathology that comes at the top of the obstetric complications in twin pregnancy, however fetal complications such as bradycardia, Placental abruption or cord procidence may occur after the birth of the first twin exposing the second to increased morbidity and mortality $[3,4]$. For some authors, these risks are especially present when delivery takes place vaginally and this depending on several parameters: presentation, mode of delivery, term, fetal weight, the difference in weight between the first and second twin [5]. The prevalence of twin pregnancy varies from region to region, country to country. Thus, the twinning rate varies between 2 and $20 \%$ in the world with the lowest in Asia [1]. The frequency of twin pregnancies has increased considerably in recent years since the advent of Assisted Reproduction (ART) techniques in developed countries. This increase is felt slightly today in Africa south of the Sahara, certainly because of an improvement in health coverage in certain areas [5]. In France, as in other so-called developed countries such as the United States and the United Kingdom, the number of twin deliveries increased by around $62 \%$ between 1970 and 1998 due to an increase in maternal age and increasing use of medically assisted procreation techniques, so that in France twins represented $3.5 \%$ of births during the last national perinatal survey $[4,6]$. The study of twin pregnancy in an African environment is of particular interest not only because of its greater frequency in black communities, but also the difficulties encountered in its diagnosis and monitoring of pregnant women [1]. In Africa, the frequency of twin births is 928 out of 80,000 births, or $1.16 \%$. And it is higher in black Africa where it is 4 to 5 times more frequent in Nigeria, Seychelles, South Africa and Zimbabwe [1]. In Guinea, a study carried out in 2009 by Baldé IS et al., reported 3.53\% twin pregnancies [7]. The aim of this work was to describe the outcome of twin pregnancies in an African environment at the maternity ward of the Ignace Deen National Hospital. Our specific objectives were to: Describe the socio-demographic characteristics of mothers who have given birth to twins, describe the peculiarities of twin births and identify the factors of poor neonatal prognosis. And it is higher in black Africa where it is 4 to 5 times more frequent in Nigeria, Seychelles, South Africa and Zimbabwe [1]. In Guinea, a study carried 
Citation: O Baldé, MH Diallo, IS Baldé, FB Diallo, H Sy, et al. (2021) Result of Twin Pregnancies at the Maternity of Ignace Deen National Hospital in Guinea. J Reprod Med Gynecol Obstet 6: 079.

- Page 2 of $6 \bullet$

out in 2009 by Baldé IS et al., reported 3.53\% twin pregnancies [7]. The aim of this work was to describe the outcome of twin pregnancies in an African environment at the maternity ward of the Ignace Deen National Hospital. Our specific objectives were to: Describe the socio-demographic characteristics of mothers who have given birth to twins, describe the peculiarities of twin births and identify the factors of poor neonatal prognosis. And it is higher in black Africa where it is 4 to 5 times more frequent in Nigeria, Seychelles, South Africa and Zimbabwe [1]. In Guinea, a study carried out in 2009 by Baldé IS et al., reported $3.53 \%$ twin pregnancies [7]. The aim of this work was to describe the outcome of twin pregnancies in an African environment at the maternity ward of the Ignace Deen National Hospital. Our specific objectives were to: Describe the socio-demographic characteristics of mothers who have given birth to twins, describe the peculiarities of twin births and identify the factors of poor neonatal prognosis. 53\% twin pregnancies [7]. The aim of this work was to describe the outcome of twin pregnancies in an African environment at the maternity ward of the Ignace Deen National Hospital. Our specific objectives were to: Describe the socio-demographic characteristics of mothers who have given birth to twins, describe the peculiarities of twin births and identify the factors of poor neonatal prognosis 53\% twin pregnancies [7]. The aim of this work was to describe the outcome of twin pregnancies in an African environment at the maternity ward of the Ignace Deen National Hospital. Our specific objectives were to: Describe the socio-demographic characteristics of mothers who have given birth to twins, describe the peculiarities of twin births and identify the factors of poor neonatal prognosis.

\section{Methodology}

This was a prospective, descriptive and analytical cross-sectional study carried out at the maternity ward of the Ignace Deen National Hospital, lasting 12 months (January 1 to December 31, 2020) on a continuous series of 253 twin deliveries. The variables studied were: the socio-demographic characteristics of pregnant and parturient women (age, profession, level of education, marital status and parity), Prenatal Monitoring Methods (ANC), mode of delivery, subsequent complications, maternal prognosis and neonatal. During the study period, the minimum cost of an antenatal consultation was $1000 \mathrm{FG}$ (US \$ 1) that of an obstetric ultrasound of 100,000 FG (10 US dollars), the guaranteed minimum interprofessional wage of $400,000 \mathrm{FG}$ or 40 US dollars. Were included in the study all pregnant and parturients who have given birth to twins or who are received in the immediate aftermath of a twin birth performed in another health facility or at home with a term pregnancy greater than or equal to 6 months (28 weeks). Not included in the study, all parturients having given birth to triplets. Data were analyzed on SPSS software. The tables and the word processing were carried out on Excel and Word 2010 software. Depending on the case, the chi-square test or exact FISHER were used for the comparison of the qualitative variables. The tests of STUDENT, Wil COXON were used for the comparison of the means or the medians after checking the conditions of application. The significance level was set at $\mathrm{P}=5 \%$. The population concerned was mainly hospitable. This work therefore did not reflect the reality of twin deliveries throughout Guinea. However, for a better understanding of our results, we had to compare them with the data in the literature.

\section{Results}

\section{Frequency}

Of the 5,478 deliveries performed in the ward during the study period, 253 were twins, i.e., a frequency of $4.62 \%$ of deliveries.

\section{Sociodemographic characteristics of parturients (Table 1)}

\begin{tabular}{|c|c|c|}
\hline $\begin{array}{c}\text { Sociodemographic Infor- } \\
\text { mation }\end{array}$ & Workforce $(\mathrm{N}=\mathbf{2 5 3})$ & Percentage \\
\hline \multicolumn{3}{|l|}{ Age } \\
\hline$<20$ & 23 & 9.1 \\
\hline 20 to 24 & 67 & 26.5 \\
\hline 25 to 29 & 84 & 33.2 \\
\hline 30 to 34 & 56 & 22.1 \\
\hline$>34$ & 23 & 9.1 \\
\hline $\begin{array}{c}\text { Extreme: } 17 \text { and } 36 \text { years } \\
\text { old }\end{array}$ & & Average: $26.63 \pm 5.3$ \\
\hline \multicolumn{3}{|l|}{ Profession } \\
\hline Student & 43 & 17 \\
\hline Housewife & 83 & 32.8 \\
\hline Official & 33 & 13 \\
\hline Liberal & 94 & 37.2 \\
\hline \multicolumn{3}{|l|}{ Level of Education } \\
\hline No schooling & 125 & 49.4 \\
\hline Primary & 42 & 16.6 \\
\hline Secondary & 38 & 15 \\
\hline University & 48 & 19 \\
\hline \multicolumn{3}{|l|}{ Marital Status } \\
\hline Single & 9 & 3.6 \\
\hline Divorcee & 1 & 0.4 \\
\hline Married & 243 & 96 \\
\hline \multicolumn{3}{|l|}{ Home } \\
\hline Dixinn & 12 & 4.7 \\
\hline Outside Conakry & 38 & 15 \\
\hline Kaloum & 22 & 8.7 \\
\hline Matam & 22 & 8.7 \\
\hline Matoto & 65 & 25.7 \\
\hline Ratoma & 94 & 37.2 \\
\hline \multicolumn{3}{|l|}{ Mode of Admission } \\
\hline Coming of herself & 165 & 65.2 \\
\hline Evacuated & 88 & 34.8 \\
\hline \multicolumn{3}{|l|}{ Parity } \\
\hline Nulliparous & 72 & 28.5 \\
\hline Primiparous & 50 & 19.8 \\
\hline Pauciparous & 90 & 35.6 \\
\hline Multiparous & 30 & 11.9 \\
\hline Large Multiparous & 11 & 4.3 \\
\hline \multicolumn{3}{|l|}{ Multiple Pregnancy DCD } \\
\hline No & 168 & 66.4 \\
\hline Yes & 85 & 33.6 \\
\hline
\end{tabular}

Table 1: Sociodemographic characteristics of women giving birth.

\section{Prenatal follow-up (Table 2)}

\begin{tabular}{|c|c|c|}
\hline CPN location & Workforce & Percentage \\
\hline Health center & 87 & 34.4 \\
\hline Private clinic & 71 & 28.1 \\
\hline CMC & 80 & 31.62 \\
\hline
\end{tabular}


Citation: O Baldé, MH Diallo, IS Baldé, FB Diallo, H Sy, et al. (2021) Result of Twin Pregnancies at the Maternity of Ignace Deen National Hospital in Guinea. J Reprod Med Gynecol Obstet 6: 079.

- Page 3 of $6 \cdot$

\begin{tabular}{|c|c|c|}
\hline $\mathrm{CHU}$ & 12 & 4.74 \\
\hline Prefectural hospital & 2 & 0.8 \\
\hline Regional hospital & 1 & 0.4 \\
\hline \multicolumn{3}{|l|}{ Number of CPNs } \\
\hline $0-1$ & 16 & 6.32 \\
\hline 2 to 3 & 110 & 43.48 \\
\hline$\geq 4$ & 127 & 50.20 \\
\hline Extremes: 0 and 8 & & Average: $3.3 \pm 1.1$ \\
\hline \multicolumn{3}{|c|}{ Diagnosis of Twin Pregnancy } \\
\hline $1^{\text {st trimester }}$ & 83 & 32.8 \\
\hline $2^{\text {nd }}$ quarter & 117 & 46.2 \\
\hline $3^{\text {rd }}$ quarter & 41 & 16.2 \\
\hline During work & 12 & 4.7 \\
\hline \multicolumn{3}{|l|}{ Obstetric Ultrasound } \\
\hline No & 8 & 3.2 \\
\hline Yes & 245 & 76.8 \\
\hline \multicolumn{3}{|l|}{ Number of Ultrasounds } \\
\hline 1 & 57 & 23.27 \\
\hline 2 & 103 & 42.04 \\
\hline 3 & 73 & 29.80 \\
\hline$\geq 4$ & 12 & 4.90 \\
\hline \multicolumn{3}{|c|}{ Complications of Pregnancy } \\
\hline No & 202 & 79.9 \\
\hline Yes & 51 & 20.1 \\
\hline \multicolumn{3}{|c|}{ Complications that Occurred During Pregnancy } \\
\hline No & 200 & 79.5 \\
\hline Yes & 53 & 20.95 \\
\hline Anemia & 15 & 5.93 \\
\hline HTA & 23 & 9.09 \\
\hline Hydramnios & 2 & 1.19 \\
\hline MAP & 10 & 3.95 \\
\hline Other & 2 & 0.79 \\
\hline \multicolumn{3}{|c|}{ Circumstances of Onset of Pregnancy } \\
\hline After infertility treatment & 32 & 12.65 \\
\hline Spontaneous & 221 & 87,35 \\
\hline
\end{tabular}

Table 2: Breakdown according to the course of the pregnancy.

\section{Delivery Method of delivery}

It was done vaginally in $45.8 \%(\mathrm{~N}=116)$ and by caesarean section in $54.2 \%(\mathrm{~N}=137)$. The indications for cesarean section were more frequently linked to obstructed presentations of D1 (43.80\%), retention of D2 (13.87\%), acute fetal distress $(12.41 \%)$, severe pre-eclampsia $(10.95 \%)$ and the scarred uterus $(10.80 \%)$. Term: the delivery was premature (term $<37 \mathrm{WA}$ ) in 123 cases or $48.62 \%$ and at term in 130 cases $(51.38 \%)$. Presentation of twins: cephalic presentation was the most frequent for the two (2) twins $(57.70 \%$ for D1 and $65.61 \%$ for D2). There were as many breech presentations in the first twin (J1) and the second twin (J2), i.e., $25.69 \%$ versus $31.22 \%$. On the other hand, there were more transverse positions in the first twin $(16.6 \%$ versus $3.16 \%$ ) (Table 3 ).

\section{Outcome of vaginal birth}

Vaginal delivery was complicated in 41 patients. These complications are distributed as follows: 19 cases of retention of the second

\begin{tabular}{|c|c|c|}
\hline Vaginal Birth & Workforce & Percentage \\
\hline Obstructed & 6 & 5.2 \\
\hline Eutocic & 110 & 94.8 \\
\hline Obstructed Labor & 1 & 16.7 \\
\hline Enclosure of the head & 1 & 16.7 \\
\hline Onset obstructed labor & 4 & 66.6 \\
\hline Dynamic obstructed labor & & \\
\hline Obstetric Maneuvers on D2 & 224 & 88.5 \\
\hline No & 29 & 11.5 \\
\hline Yes & & \\
\hline
\end{tabular}

Table 3: Modalities of vaginal birth.

twin in parturients all evacuated for the same reason (7.50\%), 16 cases of hemorrhage during delivery $(6.32 \%)$ and 10 cases of perineal tear $(2.37 \%)$. Anatomical type: twin pregnancy was more frequently dizygotic, i.e., $90.51 \%(\mathrm{~N}=229)$ against $7.91 \%$ of monozygous pregnancy $(\mathrm{N}=20)$. The dizygotic pregnancy was more frequently biamniotic bichorium (56.52\%) compared to $33.99 \%$ of biamniotic monochorial pregnancy. V. Prognosis Maternal prognosis: we recorded 3 cases of maternal death, i.e., a case fatality of $1.2 \%$ : two (2) deaths were consecutive to postpartum hemorrhage and the third linked to an eclampsic coma. Neonatal prognosis: the newborns were alive and well in $66.40 \%$ for D1 versus $51.78 \%$ for D2. They were born with acute fetal distress in $24.50 \%$ of cases for D1 versus $37.55 \%$. We recorded a rate of $91 \%$ overall perinatal mortality, of which $79 \%$ for D1 and $102.7 \%$ for $\mathrm{J} 2$. We recorded a prematurity rate of $48.62 \%$. The low birth weight (weight $<2500 \mathrm{~g}$ ) was observed in $57.31 \%$ of cases for D1 and $64.2 \%$ of cases for D2. The good Apgar score $(\geq 7)$ was obtained in a proportion of $71.15 \%$ at the first minute and $92.09 \%$ at the fifth minute for $\mathrm{J} 1$ versus $58.89 \%$ and $86.96 \%$ for $\mathrm{J} 2$. Bivariate analysis of fetal status versus Apgar score reveals that:

- A good Apgar score was observed in a proportion of 30\% if the pregnancy is monoamniotic monochorion, $76.74 \%$ if the pregnancy is biamniotic monochorion and $67.13 \%$ if the pregnancy is biamniotic bichorium for J1versus 20\%, 56, 98\% and 55.24\% for $\mathrm{J} 2$. The differences observed were statistically significant $(\mathrm{p}$-value $=$ 0.001 for D1 and 0.05 for D2)

- For the mode of delivery, the $1^{\text {st }}$ twin had a good Apgar score in a proportion of $70.54 \%$ if the delivery is by vaginal route and $65.19 \%$ if the delivery is by cesarean section versus $53,51 \%$ and $51.47 \%$ for $\mathrm{J} 2$; difference not statistically significant ( $\mathrm{p}$-value $=$ 0.47 for D1 and 0.74 for D2)

For the presentation of twins, the 1st twin had a good Apgar score in a proportion of $60.27 \%$ in the event of a cephalic presentation; $64.62 \%$ in case of breech presentation and $95.24 \%$ in case of transverse position versus $53.01 \% ; 53.43 \%$ and $25 \%$ for J2. Statistically significant difference for D1 (p-value $<0.0001$ ) and not significant for $\mathrm{D} 2$ ( $\mathrm{p}$-value $=0.28$ ). Relative to birth weight, low birth weight is a factor of poor neonatal prognosis. Indeed the good score of Apgar $(\geq 7 / 10)$ was observed in a proportion of $62.68 \%$ in case of low birth weight versus $74.24 \%$ in case of birth weight $\geq 2500 \mathrm{~g}$ for D1 versus $46.25 \%$ and $63.33 \%$ for D2. Difference not statistically significant ( $\mathrm{p}$-value $=0.054$ for D1 and 0.009 for D2). 


\section{Discussion}

\section{Frequency}

The frequency of twin pregnancies in our study is close to those reported by certain authors in the West African region, in particular: Baldé et al., [7] in the same department in 2009 (3.53\%), Moreira et al., [8] in Senegal (2.9\%) and Kouamé et al.. [9] in Ivory Coast $(4.49 \%)$. On the other hand, our frequency is higher than those reported by certain authors, in particular: Zédini et al., [10] in Tunisia (1.76\%) and Annel et al., [11] in France (1.5\%). An underestimation is undoubtedly possible in our study because of possible twin abortions that went unnoticed.

\section{Sociodemographic characteristics}

With respect to age, our pregnant women are relatively younger than that of the Epelboins series in Europe [12]. Compared to the socio-demographic realities of Europe, we have noticed a clear difference: in almost all cases, these were natural twin pregnancies in our study (only 1 case of twin pregnancy by IVF recorded) while in Europe, twin pregnancy was often the result of medical techniques for procreation (artificial insemination, in vitro fertilization or IVF and Intracytoplasmic Sperm Injection (ICSI) in women aged 35-39 years with a peak of 37 years for dizigotic pregnancies [12]. The relatively young age of the pregnant women in our series had already been reported in Senegal [8]. In relation to the profession, the majority of women were housewives, i.e., $32.8 \%$. Our pregnant women belonged to an underprivileged socio-professional category and fertilization there was exclusively natural. Unlike mothers in Europe who benefit from ART techniques partially reimbursed by social security. These techniques increase the probability of obtaining multiple pregnancies, especially twins [12]. Our result is similar to that of Traore [1] in Mali, who reported in his series that more than half of the women $(73.5 \%)$ were housewives without a remunerative profession. Regarding parity, the average parity before the current childbirth was 1.84 with extremes of 0 and 8 . However, pauciparas were the most represented (35.6\%) followed by nulliparas with $28.5 \%$. This result joins that of Moreira [8] in Senegal reporting a predominance of pauciparas in his series with $26.6 \%$; observation contrary to that of Vaast et al., [13] who estimate that twins, especially dizigote, increase with parity. Observation also contrary to that of Tiounkani et al., [5] in Mali reporting in its series a predominance of multiparas (55.61\%). The history of multiple pregnancy was found in 85 of our patients, i.e., $33.6 \%$ ( 76 twin pregnancies, 7 triple pregnancies and 2 quadruple pregnancies). Result contrary to that of Moreira in Senegal [8] reporting a rate of $4 \%$.

\section{Procedure twin pregnancy}

The high rate of prenatal consultation at health centers $(34.4 \%)$ and communal medical centers $(31.62 \%)$ could be explained by the fact that these basic health structures are closer to the populations. Regarding the number of prenatal consultations, the prenatal follow-up was not rigorous in our series: indeed, the correct number of prenatal visits required in Guinea (4 ANC) in the context of the refocused $\mathrm{ANC}$ in accordance with the recommendations of the WHO [14] was observed in only $50.2 \%$ of pregnant women; this number of ANC was recently revised upwards to 8 antenatal contacts per pregnancy. Observation of the ANC notebooks of pregnant women shows that they are poorly kept because certain parameters to note are not sought by health workers. Thus, better than the number of CPN it is the quality of the latter which is more important. The diagnosis of twinning in our series was most often made in the $2^{\text {nd }}$ trimester of pregnancy $(46.2 \%)$ followed by the $1^{\text {st }}$ trimester of pregnancy with $32.8 \%$. Finding contrary to that reported by Baldé et al., [7] in the same department 12 years ago where the diagnosis of twinning was made in most cases in the labor room (61.74\%). This difference could be explained by the improvement in the quality of prenatal follow-up, especially the accessibility of women to obstetric ultrasound. Despite all this, our result is contrary to the observation of Pons et al., [15] in France reporting that the diagnosis of twin pregnancy was made in the first trimester (before $15 \mathrm{WA}$ ) in $82.4 \%$ of cases. The authors agree in emphasizing the importance of the early diagnosis, for the fetal prognosis of twin pregnancy $[13,15,16]$, which makes it possible to set up a monitoring protocol very early on aimed at reducing the rate, prematurity and fetal hypotrophy. Obstetric ultrasound was performed in $96.8 \%$ of patients, in most cases only once and in the $2^{\text {nd }}$ trimester of pregnancy. Unfortunately in our developing countries, performing early ultrasound is very difficult due to insufficient equipment and the average cost of obstetric ultrasound which is around 100,000 GNF (or US \$10), while $50 \%$ of Guineans live below the minimum poverty line with a national income / inhabitant of less than US \$ 1 / day [17]. This is responsible for the high rate of unrecognized twin pregnancy in our series. Twinning was more frequently spontaneous in our series with $86.6 \%$ versus $13.4 \%$ of pregnancies occurring after infertility treatment. Our observation is similar to those of several African series $[5,7,8]$; on the other hand, it is contrary to those of the European series where twin pregnancy was often consecutive to ART techniques [12].

\section{Childbirth}

Childbirth most frequently took place by cesarean section, i.e., $54.2 \%$ against $45.8 \%$ vaginal delivery; higher rate than that reported by Baldé [7] in the same department 12 years ago (46.96\%). Cesarean section for retention of the $2^{\text {nd }}$ twin was performed in parturients all evacuated for the same reason, a rate linked on the one hand to the ignorance of twinning and on the other hand to the poor diagnosis of the presentation and the lack of monitoring of the patient delivered after the childbirth of D1. There are controversies over the best way to deliver a twin pregnancy Childbirth most frequently took place by caesarean section, i.e., $54.2 \%$ against $45.8 \%$ vaginal delivery; higher rate than that reported by Baldé [7] in the same department 12 years ago $(46.96 \%)$. Cesarean section for retention of the $2^{\text {nd }}$ twin was performed in parturients all evacuated for the same reason, a rate linked on the one hand to the ignorance of twinning and on the other hand to the poor diagnosis of the presentation and the lack of monitoring of the patient delivered after the childbirth of D1. There are controversies over the best way to deliver a twin pregnancy Childbirth most frequently took place by caesarean section, i.e., $54.2 \%$ against $45.8 \%$ vaginal delivery; higher rate than that reported by Baldé [7] in the same department 12 years ago (46.96\%). Cesarean section for retention of the $2^{\text {nd }}$ twin was performed in parturients all evacuated for the same reason, a rate linked on the one hand to the ignorance of twinning and on the other hand to the poor diagnosis of the presentation and the lack of monitoring of the patient delivered after the childbirth of D1. There are controversies over the best way to deliver a twin pregnancy Cesarean section for retention of the $2^{\text {nd }}$ twin was performed in parturients all evacuated for the same reason, a rate linked on the one hand to the ignorance of twinning and on the other hand to the poor diagnosis of the presentation and the lack of monitoring of the patient delivered after the childbirth of D1. There are controversies over the best way to deliver a twin pregnancy Cesarean 
Citation: O Baldé, MH Diallo, IS Baldé, FB Diallo, H Sy, et al. (2021) Result of Twin Pregnancies at the Maternity of Ignace Deen National Hospital in Guinea. J Reprod Med Gynecol Obstet 6: 079.

- Page 5 of 6 •

section for retention of the $2^{\text {nd }}$ twin was performed in parturients all evacuated for the same reason, a rate linked on the one hand to the ignorance of twinning and on the other hand to the poor diagnosis of the presentation and the lack of monitoring of the patient delivered after the childbirth of D1. There are controversies over the best way to deliver a twin pregnancy $[16,18]$. Our high rate of caesarean section could be explained by the fact that our center is the only functional center of last resort receiving obstetric evacuations from peripheral maternity hospitals in the city of Conakry and neighboring prefectures. Our cesarean rate is close to that of Zédini C [10] in Tunisia. However, the high frequency of the cesarean section in the event of twin births and especially the decision of prophylactic interventions gives rise to reflection and calls on birth attendants to work for an improvement in the quality of care. In our context, the popularization of ultrasound in the delivery room could be of considerable help in the diagnosis of presentations.

\section{Prognosis}

\section{Maternal prognosis}

Our delivery hemorrhage rate is lower than that of Moreira $\mathrm{P}[8]$ in Senegal (7.26\%) and significantly lower than that reported by Baldé IS [7] in the same department in 2009 (12.17\%). This difference could be explained by the systematic introduction in the service in recent years of AMTSL (active management of the third period of childbirth) consisting of a controlled delivery. We recorded 3 maternal deaths, i.e., a case fatality of $1.2 \%: 2$ deaths were consecutive to postpartum hemorrhage and the third linked to an eclampsic coma. Data from the literature $[19,20]$ are inanimate that maternal mortality after twin childbirth is mainly due to the increased risk of pregnancy-induced hypertension (5 to $10 \%$ of single pregnancies compared to 10 to $20 \%$ of multiple pregnancies) and increased bleeding of the breast. Postpartum due to uterine overdistension which can cause either uterine rupture or atony.

\section{Neonatal prognosis}

Our perinatal mortality rate is higher than that of Meye [21] in Gabon (40\%), but lower than that of Moreira [8] in Senegal (157\%). The classic excess mortality of D2 is also a constant in our series (102.7\%o) for $\mathrm{J} 2$ against (79\%) for $\mathrm{J} 1$ and results from complications such as hypoxia, separation of the placenta and fetal retention due to uterine retraction to which they are often exposed after giving birth to the first twin. Prematurity is also a factor of poor prognosis for newborns. Our prematurity rate $(48.62 \%)$ is higher than that of Moreira [8] in Senegal (23\%), and that of Rachidi et al., [22] in Tunisia $(28.10 \%)$; on the other hand, this rate is close to Pons et al., [15] in France $(45.96 \%)$, despite the establishment of a policy to prevent prematurity in France during twin pregnancy. As for Andriamamy [23] in Madagascar, his rate is very clearly above ours with $85 \%$ premature. Our prematurity rate could be explained by the inaccessibility of diagnostic means for twinning and the low socioeconomic level of the patients. In addition, the lack of equipment for the rearing of premature babies in the department makes their prognosis very reserved.

\section{Conclusion}

Twin pregnancy is a high risk pregnancy involving both maternal and fetal prognosis. We are of the opinion that the delivery of the second twin must be active in order to reduce the delay or interval of birth between the two twins to improve the prognosis of the latter. Apart from the delay in birth between the two twins, all the other factors seem to us to be cofactors acting through the delay in birth.

\section{References}

1. Traoré C (2015) Grossesse et accouchement gémellaires dans le Service de Gynéco-Obstétrique du Centre de Santé de Référence de la Commune II du District de Bamako. Thèse de médecine, Université de Bamako, Bamako, Mali.

2. Parant $\mathrm{O}$, Salque C, Rème JM (2004) Accouchement gémellaire : conduite à tenir pour l'accouchement du $2^{\mathrm{e}}$ jumeau. La revue sage-femme 3: 110120.

3. Camara N (2006) Les grossesses et accouchements gémellaires à la maternité de l'Hôpital National Point G: A propos d'une étude rétrospective cas-témoin de 505 grossesses gémellaires vs 18599 grossesses uniques. Thèse de médecine: 183 .

4. Schmitz T, Azria E, Cabrol D, Goffinet F (2009) L'accouchement par voie basse des grossesses gémellaires est-il encore une option raisonnable? Analyse des données de la littérature. Journal de Gynécologie Obstétrique et Biologie de la Reproduction 38: 367-376.

5. Théra T, Mounkoro N, Traore SO, Hamidou A, Traore M, et al. (2018) Accouchement gémellaire en milieu africain: Une analyse de 10 ans dans le district de Bamako au Mali. Pan Afr Med J 29: 21.

6. Sentilhes L, Bouhours A-C, Biquard F, Gillard P, Descamps P, et al. (2009) Mode d'accouchement des grossesses gémellaires. Gynécologie Obstétrique \& Fertilité 37: 432-441.

7. Baldé IS, Diallo FB, Sy T, Soumah AFM, Diallo Y, et al. (2009) La grossesse et l'accouchement gémellaire à la clinique de gynécologie et d'obstétrique Ignace Deen CHU de Conakry: aspects épidémiologiques et pronostiques. Annales de la SOGGO N 4

8. Moreira P, Lankoandé N, Cissé ML, Diouf A, Mbaye M, et al. (2007) La grossesse et l'accouchement gémellaire à la maternité du centre de santé roi Baudouin de Dakar : aspects épidémiologiques et pronostiques. Journal de la SAGGO 8: 12-15.

9. Didier DKA (2012) Pronostic néonatal dans l'accouchement du deuxième jumeau au centre hospitalier universitaire de cocody. SARAF.

10. Zedini C, Bannour R, Bannour I, Bannour B, Jlassi M, et al. (2020) L'accouchement des grossesses gémellaires et pronostic materno-fœtal dans un Centre Universitaire Tunisien de niveau 3: étude rétrospective à propos de 399 cas. PAMJ 36

11. Annel L, Waetanian R, Bouderliq CL, Rosenau L, Lirzin L. et al. (1999) Grossesse gémellaire pronostic fœtal. A propos de 100 observations. Rev Fr Gynécol Obstét 19: 508.]

12. Epelboins S, Merlet F, Bulwas M, Bulwas S, De Meidehos N. Les enfants de la FIV et de l'ICISI: mise à jour en Gynécologie et Obstétrique. Collège National des Gynécologues, Paris, France.

13. Vaast P, Lucot JP, Chauvet MP, Puech F (2000) Grossesses gémellaires et multiples. Etude anatomoclinique et prise en charge. Encycl Med Chir, Paris, France.

14. USAID (2016) Lignes Directrices de 2016 de l'OMS concernant les soins prénatals. USAID, Washington, D.C., USA.

15. Pons JC, Suares F, Duyme M, Pourade A, Vial M, et al. (1998) Prévention de la prématurité au cours du suivi de 842 grossesses gémellaires consécutives. J Gynécol Obstét Biol Reprod 27: 319-328.

16. Boubli L, Olivier S, Thoulon JM, Puech F, Boog G (1995) Les grossesses gémellaires en obstétrique. Ellipse Uref Paris: 332-342.

17. Par le Programme des Nations Unies pour le Développement (2019) Rapport sur le: développement humain 2019. PNUD, New York, USA.

18. Mathieu E (2004) Mode d'accouchement des grossesses gémellaires. Rev Prat Gynécol Obstét 81: 19-22. 
Citation: O Baldé, MH Diallo, IS Baldé, FB Diallo, H Sy, et al. (2021) Result of Twin Pregnancies at the Maternity of Ignace Deen National Hospital in Guinea. J Reprod Med Gynecol Obstet 6: 079.

- Page 6 of 6 -

19. Tauzin M, Felix A, Michot C, Dedieu C Aoust L, et al. (2017) Le monde des jumeaux: Aspects épidémiologiques et génétiques, enjeux obstétricaux, risques spécifiques et devenir. Archives de Pédiatrie 24: 1299-1311.

20. Collège National des Gynécologues et Obstétriciens Français (2009) Recommandations pour la pratique clinique: Grossesses gémellaires. J Gynécol Obstét Biol Reprod 38: 3-131.

21. Meye J-F, Zue AS, Ngou J-PNM, Engogah-Beka T (2001) Pronostic de l'accouchement gémellaire en milieu africain. Santee 11: 914
22. Rachdi R, Fekih MA, Mouelhi C, Brahim H (1992) Problèmes posés par l'accouchement de la grossesse gémellaire. Revue Française de Gynécologie et d'obstétrique 87: 295-298.

23. Andriamady RCL, Rasoarinavalona AR, Ranjalahy RJ (1999) Prise en charge des grossesses multiples à la Maternité de Befelatanana Centre Hospitalier Universitaire d'Antananarivo (Madagascar): à propos de 143 cas. Arch Inst Pasteur Madagascar 65: 103-106. 


\section{H}

Advances In Industrial Biotechnology | ISSN: 2639-5665

Advances In Microbiology Research | ISSN: 2689-694X

Archives Of Surgery And Surgical Education | ISSN: 2689-3126

Archives Of Urology

Archives Of Zoological Studies | ISSN: 2640-7779

Current Trends Medical And Biological Engineering

International Journal Of Case Reports And Therapeutic Studies | ISSN: 2689-310X

Journal Of Addiction \& Addictive Disorders | ISSN: 2578-7276

Journal Of Agronomy \& Agricultural Science | ISSN: 2689-8292

Journal Of AIDS Clinical Research \& STDs | ISSN: 2572-7370

Journal Of Alcoholism Drug Abuse \& Substance Dependence | ISSN: 2572-9594

Journal Of Allergy Disorders \& Therapy | ISSN: 2470-749X

Journal Of Alternative Complementary \& Integrative Medicine | ISSN: 2470-7562

Journal Of Alzheimers \& Neurodegenerative Diseases | ISSN: 2572-9608

Journal Of Anesthesia \& Clinical Care | ISSN: 2378-8879

Journal Of Angiology \& Vascular Surgery | ISSN: 2572-7397

Journal Of Animal Research \& Veterinary Science | ISSN: 2639-375

Journal Of Aquaculture \& Fisheries | ISSN: 2576-5523

Journal Of Atmospheric \& Earth Sciences | ISSN: 2689-8780

Journal Of Biotech Research \& Biochemistry

Journal Of Brain \& Neuroscience Research

Journal Of Cancer Biology \& Treatment | ISSN: 2470-7546

Journal Of Cardiology Study \& Research | ISSN: 2640-768X

Journal Of Cell Biology \& Cell Metabolism | ISSN: 2381-1943

Journal Of Clinical Dermatology \& Therapy | ISSN: 2378-8771

Journal Of Clinical Immunology \& Immunotherapy | ISSN: 2378-8844

Journal Of Clinical Studies \& Medical Case Reports | ISSN: 2378-880

Journal Of Community Medicine \& Public Health Care | ISSN: 2381-1978

Journal Of Cytology \& Tissue Biology | ISSN: 2378-9107

Journal Of Dairy Research \& Technology | ISSN: 2688-9315

Journal Of Dentistry Oral Health \& Cosmesis | ISSN: 2473-6783

Journal Of Diabetes \& Metabolic Disorders | ISSN: 2381-201X

Journal Of Emergency Medicine Trauma \& Surgical Care | ISSN: 2378-8798

Journal Of Environmental Science Current Research | ISSN: 2643-5020

Journal Of Food Science \& Nutrition | ISSN: 2470-1076

Journal Of Forensic Legal \& Investigative Sciences | ISSN: 2473-733X

Journal Of Gastroenterology \& Hepatology Research | ISSN: 2574-2566
Journal Of Genetics \& Genomic Sciences | ISSN: 2574-2485

Journal Of Gerontology \& Geriatric Medicine | ISSN: 2381-8662

Journal Of Hematology Blood Transfusion \& Disorders | ISSN: 2572-2999

Journal Of Hospice \& Palliative Medical Care

Journal Of Human Endocrinology | ISSN: 2572-9640

Journal Of Infectious \& Non Infectious Diseases | ISSN: 2381-8654

Journal Of Internal Medicine \& Primary Healthcare | ISSN: 2574-2493

Journal Of Light \& Laser Current Trends

Journal Of Medicine Study \& Research | ISSN: 2639-5657

Journal Of Modern Chemical Sciences

Journal Of Nanotechnology Nanomedicine \& Nanobiotechnology | ISSN: 2381-2044

Journal Of Neonatology \& Clinical Pediatrics | ISSN: 2378-878X

Journal Of Nephrology \& Renal Therapy | ISSN: 2473-7313

Journal Of Non Invasive Vascular Investigation | ISSN: 2572-7400

Journal Of Nuclear Medicine Radiology \& Radiation Therapy | ISSN: 2572-7419

Journal Of Obesity \& Weight Loss | ISSN: 2473-7372

Journal Of Ophthalmology \& Clinical Research | ISSN: 2378-8887

Journal Of Orthopedic Research \& Physiotherapy | ISSN: 2381-2052

Journal Of Otolaryngology Head \& Neck Surgery | ISSN: 2573-010X

Journal Of Pathology Clinical \& Medical Research

Journal Of Pharmacology Pharmaceutics \& Pharmacovigilance | ISSN: 2639-5649

Journal Of Physical Medicine Rehabilitation \& Disabilities | ISSN: 2381-8670

Journal Of Plant Science Current Research | ISSN: 2639-3743

Journal Of Practical \& Professional Nursing | ISSN: 2639-568

Journal Of Protein Research \& Bioinformatics

Journal Of Psychiatry Depression \& Anxiety | ISSN: 2573-0150

Journal Of Pulmonary Medicine \& Respiratory Research | ISSN: 2573-0177

Journal Of Reproductive Medicine Gynaecology \& Obstetrics | ISSN: 2574-2574

Journal Of Stem Cells Research Development \& Therapy | ISSN: 2381-2060

Journal Of Surgery Current Trends \& Innovations | ISSN: 2578-7284

Journal Of Toxicology Current Research | ISSN: 2639-3735

Journal Of Translational Science And Research

Journal Of Vaccines Research \& Vaccination | ISSN: 2573-0193

Journal Of Virology \& Antivirals

Sports Medicine And Injury Care Journal | ISSN: 2689-8829

Trends In Anatomy \& Physiology | ISSN: 2640-7752

Submit Your Manuscript: https://www.heraldopenaccess.us/submit-manuscript 